\title{
DA COMPRA-E-VENDA SUJEITA A PESAGEM, CONTAGEM E MEDIÇÃO E O PROBLEMA DOS RISCOS DA COISA VENDIDA ("PERICULUM REI VENDITAE")
}

\author{
THE CONTRACT OF SALE SUBJECT TO WEIGHING, COUNTING AND MEASURING AND THE \\ CONTROVERSY REGARDING THE RISK OF THE THING SOLD (“PERICULUM REI VENDITAE”)
}

\section{Eduardo C. Silveira Marchi}

\begin{abstract}
Resumo:
No estudo da emptio venditio de res quae pondere numero mensura constant(Gai. 10 "ed. prov." D. 18, 1, 35, 5 a 7), vale dizer, da compra-e-venda sujeita a pesagem, contagem e medição, em sua relação com a questão dos riscos pela perda ou deterioração fortuita da coisa vendida, são examinadas as principais propostas de reconstrução histórico-dogmática, em especial aquelas de V. Arangio-Ruiz, M. Kaser e W. Ernst, representantes da communis opinio, favorável à classicidade do princípio periculum est emptoris, de F. Haymann, líder da antiga e minoritária corrente radical contrária (periculum est venditoris) e, basicamente, de $\mathrm{M}$. Talamanca, cuja opinião parece a mais aceitável, autor de nova tese original sobre o tema, que justifica a contradição das fontes ao hipotisar a presença de mais uma eventual controvérsia, no direito romano clássico, entre as Escolas dos Sabinianos e dos Proculeianos, com o acolhimento pelos primeiros do princípio "p.e.v." e do dogma contrário "p.e.e." pelos últimos.
\end{abstract}

Palavras-chave: Contrato de compra-e-venda. Emptio venditio. Risco. Periculum.

\begin{abstract}
:
In this study of the emptio venditio of res quae pondere numero mensura constant (Gai. 10 "ed. prov."D. 18, 1, 35, 5 to 7), that is, of the contract of sale subject to weighing, counting and measuring and its relationship to the discussion regarding the risk for the loss or fortuitous deterioration of the thing sold, we explore the main historical and dogmatic reconstructive propositions, especially those advanced by $\mathrm{V}$. Arangio-Ruiz, M. Kaser and W. Ernst, representatives of the communis opinio that places the periculum est emptoris principle in the classical period, by F. Haymann, who headed an old and radical opposing view (periculum est venditoris) and, more importantly, by M. Talamanca, whose opinion appears to be the most acceptable one, as he is the author of an original new thesis on the subject that justifies the contradictions present in the sources by advancing the hypothesis of the existence of yet another controversy in Roman classical law between the Sabinian and Proculean schools, the former adopting the "p.e.v." principle and the latter rallying around the opposing "p.e.e." dogma.
\end{abstract}

Keywords: Contract of sale. Emptio venditio. Risk. Periculum.

Ex-diretor e Professor Titular de Direito Romano do Departamento de Direito Civil da Faculdade de Direito da Universidade de São Paulo. 


\section{Conceito do instituto}

A compra-e-venda sujeita a pesagem, contagem e medição, também denominada, na terminologia jurídica pátria, "venda a peso" "à conta" e "peso à medida" 1 vale dizer, a emptio venditio de res quae pondere numero mensura constant ${ }^{2}$ é aquela em que, como nos ensina L. Cunha Gonçalves, ${ }^{3}$ o preço é estipulado por unidades de peso, número ou medida, quer no caso do contrato abarcar parte de um todo existente em determinado lugar, quer na hipótese de referir-se à sua totalidade.

São exemplos destas espécies de contrato: por pesagem, a compra-e-venda de cem toneladas de parte do açúcar, ou de todo o açúcar, contido no armazém de Tício, a um preço certo por quilo; por contagem, a compra-e-venda de cem carneiros de parte do rebanho de Tício, ou de todo o rebanho, existente em sua fazenda, a um preço certo por cabeça; e por medição, a compra-e-venda de cem litros de parte do azeite, ou de todo o azeite, depositado nas cubas de armazenamento de Tício, a um preço certo por litro.

Esse tipo de compra-e-venda é também chamado, nos estudos romanísticos, de emptio venditio ad mensuram, isto é venda ad mensuram, eis que serve a indicar toda espécie de venda em que se impõe, para individualização da coisa, a sua mensura, vale dizer, o ato de sua "medição" em sentido amplo, ou seja, medir, quantificar, estabelecer a específica grandeza ou proporção da coisa a ser adquirida.

Na terminologia jurídica do direito moderno, este sentido amplo de venda ad mensuram foi mantido: no direito civil pátrio, por exemplo, esse tipo de venda costuma ser classificado como uma das espécies de "venda a contento" (também chamada pactum ad gustum ou pactum displicentiae), em que os efeitos do contrato ficam sujeitos à condição suspensiva dependente do agrado ou não do comprador, circunstância verificável, nesses casos, só depois da pesagem, contagem ou medição.

Nesse sentido, era o que o CC/1916 expressamente previa, ao declarar, cuidando da venda a contento (art. 1.144, caput), que "nesta espécie de venda, se classifica a dos gêneros, que se costumam provar, medir, pesar, ou experimentar antes de aceitos" (art. 1.144, parágrafo único). Não obstante a supressão de tal preceito pelo CC/2002, em que o correspondente art. 509 não apresenta parágrafo único específico ${ }^{4}$, a civilística pátria atual continua a incluir - ao que parece ${ }^{5}$ - a venda sujeita a pesagem, contagem e medição como um tipo de venda a contento.

Cf. SILVA, O. J. de Plácido e. Vocabulário jurídico. 25. ed. Rio de Janeiro:, 2004. p. 1.467.

Cf. Gai. 10 ed. prov. D. 18, 1, 35, 5.

GONÇALVES, L. Cunha. Da compra-e-venda no direito comercial brasileiro. 2. ed. São Paulo: 1950. p. 269.

Não obstante a previsão do seguinte art. 510 , com limitação expressa, porém, à venda sujeita a prova.

Cf., nesse sentido, v.g., DINIZ, M. H. Curso de direito civil brasileiro. Teoria das obrigações contratuais e extracontratuais. 26. ed. São Paulo: 2010. v. 3, p. 209, e VENOSA, S. Salvo. Direito civil: contratos em 
Não obstante a presença, ainda hoje, de tal sentido lato do termo, a expressão venda ad mensuram, contudo, é mais conhecida quando referida a uma de suas espécies, prevista no art. 500 do CC/2002, vale dizer, aquela relativa à venda de imóvel em que se estipula o preço "por medida de extensão" ou por determinação da sua "respectiva área" Trata-se, portanto, do sentido estrito da expressão "venda ad mensuram". Em contraposição a essa, apresenta-se a chamada "venda ad corpus", sempre limitadamente a imóveis, em que "não se tem em mente a extensão do imóvel determinada por medida geométrica, mas, tão simplesmente, o seu corpo, compreendido ou determinado por suas divisas, ou pelos limites declarados",, 6 em que tal referência às dimensões seja de presumir-se apenas "enunciativa" (art. 500, $\S 1^{\circ}$.).

Ressalte-se que, na história econômica e jurídica, tal tipo de compra-evenda, sempre apresentou enorme importância, dado o fato de que, na praxe do comércio, especialmente nas vendas no varejo, a aquisição de bens alimentícios, por muitos séculos, se realizava mediante tais atos de contagem, medição e pesagem. Nos dias atuais, contudo, perdeu tal espécie de contrato essa importância que tinha no passado, eis que, a partir de meados do último século XX, com o advento dos supermercados, a venda no varejo desses tipos de mercadoria passou a ser feito com base em empacotamento prévio.

Talvez por disso, na civilística mais recente, são poucos os estudiosos a dedicar maior atenção a esse tipo de contrato de compra-e-venda.

\subsection{Venda de gênero ilimitado e limitado}

Sendo o instituto jurídico em exame um tipo de compra-e-venda tendo por objeto coisas fungíveis, as quais, no mais das vezes, se referem às chamadas "obrigações genéricas", apresenta-se, no Direito Romano o problema da emptio venditio de genus, isto é, a chamada "venda de gênero"

Distinguem-se, nesse aspecto, dois tipos de genus: o chamado illimitatum ou "puro" e o limitatum.

No primeiro, tem-se um gênero ou "categoria" (com maior ou menor amplidão) de certas coisas ou mercadorias, sem que sejam elas, porém, especificadas e identificadas com precisão, como, por exemplo", 7 uma ânfora (vinte e seis litros) de azeite de Andaluzia da Espanha (olium Baeticum), ou cem módios (modii) ( novecentos litros) de trigo de Alexandria do Egito (triticum Alexandrinum), ou ainda três tonéis (dolia) de litros de vinho de Falerno da Itália (vinum Falernum).

espécie. 10. ed. São Paulo: 2010. p. 61, e Código civil interpretado. 2. ed. São Paulo: 2011. p. 615. 6 Cf. SILVA, O. J. de Plácido e. Vocabulário jurídico. 25. ed. Rio de Janeiro: 2004. p. 1.466.

7 Cf. ABATINO, B. L'"emptio venditio" di "res quae pondere numero mensura constant"- Principi, giuristi, prassi. 2005-2006. Tese (Doutorado) - Università degli Studi di Napoli "Federico Il", Napoli. p. 10-11. 
Já no segundo, por sua vez, tem-se uma "categoria" (com maior ou menor amplidão) de determinadas coisas ou mercadorias, mas com uma clara e expressa especificação e identificação, ou, pode-se dizer, de certa quantidade de um genus de coisas a serem individualizadas em um específico depósito existente em um determinado lugar $^{8}$ São exemplos, em contrapartida àqueles acima mencionados: uma ânfora de azeite de Andaluzia depositada nos armazéns pertencentes a Barbácia (horrea Bartatiana), localizados na cidade portuária de Pozzuoli na Itália (colônia Iulia Augusta Puteoli), ou cem módios de trigo de Alexandria transportados pelo navio de Sauféio (Saufeius), ou três tonéis (dolia) de vinho de Falerno guardados na adega (cella vinaria) de Marcos Ágrio.

Enquanto no Direito moderno admite-se sem dificuldade a compra-e-venda de gênero, ainda que ilimitado (como previsto, por exemplo, nos arts. 1378 do CC. italiano e 1585 do francês), as fontes romanas, não obstante oferecerem uma rica casuística de obrigações genéricas nascidas tanto da stipulatio quanto do legato per damnationem ${ }^{9}$, parecem não reconhecer a venda puramente de genus, isto é, sem qualquer limitação ou especificação, ou seja, de um bem quando individualizado exclusivamente por pertencer a uma categoria. ${ }^{10}$

A questão, todavia, continua controvertida. Apesar de algumas manifestações dissidentes, ${ }^{11}$ a amplíssima maioria dos intérpretes modernos, dos pandectístas aos estudiosos atuais, nega a admissão, pelo direito romano, da chamada "Gattungskauf" ou "venda de gênero" illimitatum. ${ }^{12}$

8 Cf. FERCIA, R. "Emptio perfecta" e vendita di genere: sul problema del "tradere" in C 4.48.2. In: GAROFALO, L. (Org.). La compravendita e l'interdipendenza delle obbligazioni nel diritto romano I. Padova: 2007. p. 701.

9 Cf. MARRONE, M. Istituzioni di diritto romano. 2. ed. Palermo: 1996. p. 438-439.

10 Cf. ABATINO, B. L'"emptio venditio"cit., p. 6.

1 Cf., por exemplo, no passado, RABEL, E. Gefahrtragung beim Kauf. ZSS 99 (1921), p. 555 e H. Siber, Römisches Recht 2, Berlin, 1928, pp. 194 e ss., e, em época mais recente, W. Kunkel - H. Honsell, Römisches Recht, Berlin-Heidelberg, 1987, p. 306 nota 6 e C.A. Cannata, La compravendita consensuale romana: significato di uma struttura, in Vendita e trasferimento della proprietà nella prospettiva storicocomparatistica 2, Milano, 1991.p. 416. nota 18.

12 Cf. detalhada descrição da bibliografia em ABATINO, B. L"'emptio venditio" cit., p. 6-8, nota 17 , destacando-se: DEREMBURG, H. Pandekten 2. 5. ed. Berlin: 1897. p. 258 e not. 18, KARLOWA, O. Römische Rechtsgeschichte 2. Leipzig: 1901. p. 615, LEVY, E. Seckel-E. Die Gefahrtragung cit., p. 117 e ss., P. F. Girard, Manuel élémentaire de droit romain, $8^{\circledR}$. ed., Paris, 1929, p. 573 nota 5, BUCKLAND, W.W. A Text-Book of Roman Law. 2. ed. Cambridge, 1950. p. 484, ZIMMERMANN, R. The Law of Obligations. Roman Foundation of the Civilian Tradition. Cape Town, 1990, p. 236 e ss., ARANGIO-RUIZ, V. La compravendita in diritto romano 1. 2. ed. Napoli, 1956, p. 122 e ss., GUARINO, A. Diritto privato romano. 12. ed. Napoli, 2001. p. 885 e nota 77.2, BURDESE, A. Vendita (dir. rom.), in NNDI - Nuovissimo Digesto Italiano 20 (1975). p. 596, MARRONE, M. Istituzioni di diritto romano. 2.ed. Palermo, 1994. p. 438-439, TALAMANCA, M. Vendita (dir. rom.). In: Enciclopedia del Diritto 46 (1993), p. 457 e nota 1600, LOPES, M.M. Benitez. La venta de vino y otras mercancias em la jurisprudência romana. Madrid, 1994. p. 67 e 106, KASER, M. Römisches Privatrecht. Das altrömische, das vorklassische und klassische Recht. 2. ed. München: 1972. p. 548, PENNITZ, M. Das periculum rei venditae - Ein Beitrag zum "Aktionenrechtlichen Denken" im römischen Privatrecht. Wien, 2000. p. 327 e ss., HONSELL, H. Römisches Recht. 4. ed. Berlin- 


\section{Venda "ad mensuram" e "periculum rei venditae"}

O estudo desse tipo de contrato de compra-e-venda apresenta, como veremos mais adiante, grande relevância no âmbito da vexata quaestio, em Direito Romano, concernente ao problema do periculum rei venditae (no Direito Romano), vale dizer, dos riscos decorrentes do perecimento fortuito (da perda fortuita) da coisa vendida.

Recorde-se a questão: celebrado um contrato de compra-e-venda (emptio venditio) e ainda não entregue a coisa vendida, a quem caberá o prejuízo caso a mercadoria (merx) se destrua ou se deteriore por caso fortuito ou de força maior, vale dizer, sem qualquer conduta culposa tanto do vendedor (venditor) quanto do comprador (emptor)?

A essa relevante questão, o moderno direito civil responde imputando o prejuízo - e, portanto, os riscos da coisa - ao contratante proprietário da coisa vendida: "res perit domino" Tal princípio costuma também ser indicado pelo adágio "casum sentit dominus". ou seja, o proprietário suporta o caso fortuito ou de força maior.

Com base nessa solução, o Direito brasileiro, ${ }^{13}$ a exemplo de alguns outros ordenamentos modernos, especialmente o alemão, ${ }^{14}$ atribui os riscos, uma vez celebrada a compra-e-venda, ao vendedor - "periculum est venditoris".

Essa é a solução daqueles ordenamentos modernos, como o alemão e o nosso, em que a simples celebração do contrato gera apenas efeitos obrigacionais. ${ }^{15}$

Assim, enquanto não ocorrida a transferência da propriedade da coisa vendida por meio de sua tradição ou entrega (no caso de coisas móveis), o vendedor, por estar ainda na condição de proprietário, arca com os riscos pela eventual perda fortuita daquela.

Por outro lado, nos ordenamentos atuais - como o francês e o italiano - em que o mero aperfeiçoamento do contrato produz o efeito da translação da propriedade da coisa vendida, os riscos, logo após a celebração da compra-e-venda, são do comprador, por ser ele o novo proprietário.

Já o Direito Romano, em contrapartida, parece nesse ponto adotar solução diversa, em completa oposição à sistemática moderna: os riscos, uma vez celebrada a emptio venditio, caberiam ao comprador - "periculum est emptoris" -, mesmo não tendo

Heildelberg, 1997. p. 113, Hausmaninger, H.; SELB, W. Römisches Privatrecht. 4. ed. Köln, 1997. p. 301.

13 V. art. 492, caput, do CC/2002: "Até o momento da tradição, os riscos da coisa correm por conta do vendedor, e os do preço por conta do comprador"

$14 \quad$ V. § 446 I I do BGB: "Mit der Übergabe der verkauften Sache geht die Gefahr des zufälligen Unterganges und einer zufälligen Verschlechterung auf den Käufer über" (=com a entrega da coisa vendida o perigo do perecimento acidental e de uma deterioração casual passa para o comprador).

15 Repetindo, nesse ponto, o sistema do Direito Romano, pelo menos no período clássico: cf. BIONDI, B. Istituzioni di diritto romano. 4. ed. Milano, 1972. p. 488 e n. 84. 
havido ainda a tradição da coisa vendida, ou melhor, independentemente da questão da transferência ou não da propriedade.

Assim, na aparente sistemática romana, o periculum decorrente da destruição da merx por caso fortuito ou de força maior passaria ao comprador desde o momento do aperfeiçoamento do contrato: ele seria obrigado a pagar o preço, não obstante deixasse de receber a coisa perecida.

São inúmeras, nesse sentido, as fontes romanas em que se declara, de modo explícito e taxativo, que os riscos cabem ao comprador ainda ante traditionem $^{16}$.

Mostrar-se-ia, pois, difícil ao intérprete, a primeira vista, duvidar dessa solução romana.

Todavia, esse pretenso dogma romano do periculum est emptoris sempre causou surpresa entre os intérpretes modernos, dada a sua possível iniqüidade.

Injusta seria essa regra de atribuição dos riscos ao comprador desde a celebração, em primeiro lugar, pelo fato de o mesmo nem ao menos ter ainda recebido a coisa vendida. O emptor, pois, responderia pelo prejuízo decorrente do perecimento da coisa não tendo sequer a mesma sob a sua guarda. Se os riscos fossem dele, seria imperioso que pudesse ao menos guardá-la com extrema precaução, de maneira a diminuir ao máximo a probabilidade de seu desaparecimento por algum tipo de vis maior.

Por outro lado, essa aparente iniqüidade da regra romana encontraria também confirmação ao se invocar o princípio cuius commoda eius et incommoda (aplicando-o ao caso do proprietário-vendedor): o dono da coisa, ao beneficiar-se das consequências vantajosas de sua posição jurídica (aquisição dos frutos, das acessões etc.), deveria também suportar, como contrapeso, as circunstâncias desfavoráveis dela decorrentes (depreciação natural da coisa, seu perecimento parcial ou total etc.)

Nestes termos, pareceria estranho, na solução romana, que o comprador, não sendo ainda proprietário da coisa, devesse arcar com uma circunstância altamente desfavorável para ele (suportar o prejuízo pela eventual perda fortuita da merx), sem gozar de qualquer conseqüência vantajosa decorrente da posição (ainda faltante) de dono.

Por fim, a perplexidade do intérprete moderno diante dessa prevalente regra das fontes romanas decorre da sua evidente contrariedade em relação ao princípio da interdependência das prestações nos contratos bilaterais baseados na boa-fé: tornando-se impossível o cumprimento da prestação por uma das partes, sem que tenha havido sua culpa, impõe-se exonerar a outra parte de sua obrigação. ${ }^{17}$ Em outros termos, nos contratos

\footnotetext{
16 Cf. especialmente Paul. 33 ad. ed., D. 18, 1, 34, 6 e D. 18, 6, 8 pr., Pomp. 4 resp., D. 23, 2, 15 e Diocl. et Max. C. 4, 48, 6 (de 294 d.C.).

17 Cf. MARRONE, M. Istituzioni cit., p. 485.
} 
sinalagmáticos, como se sabe, uma parte nunca pode exigir a execução da prestação pela outra parte sem que tenha, por sua vez, cumprido a sua.

\subsection{A doutrina romanística diante de tal problema}

Apesar da estranheza ou perplexidade dos intérpretes modernos defronte à pretensa regra romana, a doutrina dominante e quase unânime dentre os intérpretes do direito romano, até o final do séc. XIX, era a de que o aparentemente iníquo dogma periculum est emptoris, de atribuição de riscos ao comprador mesmo não tendo ele ainda recebido a merx, ter-se-ia mantido absoluto na Roma antiga, ou seja, com vigência ampla e sem quaisquer restrições, tanto em época clássica quanto justinianéia. ${ }^{18}$

Não obstante a presença, já a partir do séc. XVI, de vozes raras e isoladas, como a dos antigos intérpretes Vangerow e Cujácio, admitindo ter o dogma periculum est emptoris sofrido algumas limitações por parte dos romanos, foi só ao final do séc. XIX e início do séc. XX que alguns poucos estudiosos passaram a avançar tese radical contrária à communis opinio.

Essa também é a época em que floresce a crítica interpolacionística, com a chamada "caça às interpolações" (Interpolationenjagd) e a consequente reconstrução histórico-dogmática diferenciada entre o direito romano clássico e o direito romano justinianeu.

O primeiro deles foi C. Arnò, o qual, em uma série de escritos, ${ }^{19}$ buscou negar o caráter clássico do princípio periculum est emptoris, individualizando na traditio o momento de passagem do risco do vendedor ao comprador. O Direito Romano clássico, portanto, teria acolhido princípio oposto: periculum est venditoris (ante traditionem).

A regra de imputação dos riscos ao comprador configuraria obra dos compiladores, sendo o periculum emptoris um dogma bizantino, a caracterizar, pois, o Direito Romano justinianeu.

A tese de C. Arnò foi, em seguida, retomada de forma muito mais aprofundada por F. Haymann, ${ }^{20}$ que, em dois estudos fundamentais sobre o assunto, consolidou essa

18 Daí, aliás, a forte reação contrária do moderno Direito Civil positivo, com a adoção de solução diversa, baseada no princípio "res perit domino" Recorde-se, nesse sentido, a adoção desse último dogma, em especial, pelo Código Prussiano de 1794, seguido pelo BGB de 1896 (cf. nota 2 supra), com o que se inverteu o princípio romano, fazendo recair os riscos sobre o vendedor - "periculum est venditoris" -, ou seja, o proprietário da coisa vendida enquanto não realizada a traditio. Por influência da doutrina alemã, vários ordenamentos modernos, como o nosso, seguiram o mesmo caminho.

19 Cf. La teorica del periculum rei venditae nel diritto romano classico. Giurisprudenza Italiana, 49, 1987. p. 209 ss.; Note minime sul 33 Inst. 3,23, in AG (Archivio Giuridico) 62 (1899), p. 540 ss.; La costituzione ultima del Códice de periculo et commodo rei venditae, in Studi Brugi 1910, p. 154 ss.; e Sul c. 23 dei Fragmenta Vaticana, in Memorie della R Academia di Scienze Lettere ed Arti in Modena 9 (1910), p. 73 ss.

20 Cf. Textkritische Studien zum römischen Obligationenrecht. I- Über Haftung für custodia. II- "Periculum est emptoris", in ZSS (Zeitschrift der Savigny-Stiftung für Rechtsgeschichte) 40 (1919), pp. 167 ss. e pp. 44 ss.; 
reconstrução histórico-dogmática acerca do periculum rei venditae, passando a capitanear tal importante corrente minoritária, em oposição à communis opinio.

As conclusões de F. Haymann foram, em seguida, acolhidas de maneira integral por M. Konstantinovitch, ${ }^{21} \mathrm{e}$, mais tarde, retomadas, em seu núcleo central, por E. Betti, $^{22}$ sendo ele acompanhado, sem modificações substanciais, por M. Sargenti. ${ }^{23}$

A reação aos estudos críticos de F. Haymann coube a E. Seckel-E. Levy, ${ }^{24}$ os quais, em aprofundado estudo, foram os responsáveis, por assim dizer, pela refundação ${ }^{25}$ da doutrina dominante.

Em sua reconstrução histórico-dogmática e em defesa da doutrina tradicional, E. Seckel-E. Levy sustentaram, em primeiro lugar, que o princípio "periculum est emptoris" teria gozado de ampla vigência no direito romano clássico - independentemente, pois, da ocorrência ou não da traditio-, contanto que, todavia, a compra-e-venda tivesse alcançado o estágio de emptio perfecta.

Tal estágio corresponderia a casos excepcionais, como os da compra-evenda sujeita a condição suspensiva (Paul., 33 ad Ed., D. 18, 6, 8 pr.) e aquela dependente de contagem, medição e pesagem (Gai, 10 ad ed. Prov., D. 18, 1, 35, 5 e 7, Frag. Vat. 16 e Alex. C. 4, 48, 2, 1-2 [de 223 d.C.]).

Nessas situações excepcionais, não obstante já "celebrada" a comprae-venda, os riscos ainda caberiam ao vendedor. Só depois de verificada a condição, na primeira hipótese, ou de individualizada, na segunda, de modo claro e específico a coisa vendida - vale dizer, apenas em seguida ao "aperfeiçoamento" do contrato -, é que os riscos se transfeririam ao comprador, ou seja, passaria a ter validade o princípio "periculum est emptoris"

Com isto, tal dogma clássico viria, em parte, mitigado.

Por outro lado, ainda segundo E. Seckel-E. Levy, outra importante atenuação do princípio decorreria de uma pretensa responsabilidade por custodia do vendedor.

Tal figura, presente em outras relações jurídicas do Direito Romano, como, v.g., nos contratos de comodato e de transporte marítimo, mas desconhecida (nesse sentido técnico) do moderno Direito Civil, corresponderia a uma espécie de responsabilidade objetiva, ou seja, sem culpa do devedor, em que ele (o devedor) responderia por furto ou

e Zur klassizität des "periculum emptoris", in ZSS (Zeitschrift der Savigny-Stiftung für Rechtsgeschichte) 48 (1928), p. 314 ss.

21 Le "periculum rei venditae" em droit romain, Lyon, 1923.

22 Cf. "Periculum" - Problemi del rischio contrattuale in diritto romano clássico e giustinianeo, in JUS 5 (1954), pp. 333 ss. [=Studi in onore di $P$. de Francisci I, Milano, 1956, p. 131 ss.

23 Cf. Rischio contrattuale (diritto romano), in ED (Enciclopedia del Diritto) 40 (1989), p. $1126 \mathrm{ss.}$

24 Die Gefahrtragung beim Kauf im klassischen römischen Recht, in ZSS (Zeitschrift der Savigny-Stiftung für Rechtsgeschichte) 47 (1927), p. 117 ss.

25 É a expressão empregada por M. Talamanca: cf. Considerazioni sul "periculum rei venditae", in Seminarios Complutenses de Derecho Romano 7 (1995), p. 222, n. 13, o mais importante estudioso atual do tema. 
casus minor, vale dizer, um grau menor (de resistência) dentre as espécies de caso fortuito ou de força maior.

Assim, em conclusão, o dogma pretensamente clássico periculum est emptoris indicaria a responsabilidade do comprador apenas nos casos mais graves de casus (v.g., roubo) e vis maior (v.g., eventos naturais). Nas situações menos graves de casus minor (v.g., furto), os riscos caberiam ao vendedor.

Esses são, em linhas gerais, os pontos principais da tese dominante em nosso tema.

Portanto, para grande maioria dos estudiosos de Direito Romano da atualidade, ${ }^{26}$ a regra de atribuição do risco da coisa vendida ao comprador, nos limites especificados por E. Seckel-E. Levy, corresponderia à exata situação do direito de época clássica em Roma.

Todavia, não faltam autores, mesmo em época relativamente recente, com posições inclusive mais radicais em prol do princípio periculum est emptoris, ou seja, sem as restrições trazidas por E. Seckel-E. Levy.

São os casos de W. Ernst ${ }^{27}$ e G. Thielmann. ${ }^{28} \mathrm{O}$ primeiro refuta a doutrina da emptio perfecta do modo como acima exposto, entendendo que o "aperfeiçoamento" da compra-e-venda indicaria, na verdade, o momento do início de validade jurídica do próprio contrato; nega, assim, a existência qualquer exceção ao dogma de atribuição dos riscos ao comprador. ${ }^{29}$ Já o segundo procura demonstrar, por meio da exegese de alguns fragmentos, ${ }^{30}$ que a realização da traditio não teria qualquer importância no tocante à distribuição de riscos entre o vendedor e comprador.

Por fim e em contrapartida, já em relação à doutrina minoritária, que nega a vigência ilimitada do princípio periculum est emptoris, continuam a aparecer, ainda hoje, estudos esporádicos, mesmo que de forma isolada, como ocorrido, no passado, com os trabalhos de C. Arnò, F. Haymann e E. Betti, acima mencionados.

26 Para a literatura nesse sentido, cf. M. Kaser, Das römische Privatrecht I cit. p. 552, e M. Talamanca, Vendita (diritto romano), in Enciclopedia del Diritto 46 (1993), p. 449, n. 1517. Dentre os trabalhos relevantes da historiografia menos atual, cf. especialmente a obra fundamental de V. Arangio-Ruiz, La compravendita in diritto romano II, Napoli, 1956 (reimpr.), pp. 205 ss.. Quanto à época mais relativamente recente, dentre os estudos significativos em defesa da tese tradicional, cf., de modo especial, F. Peters, Periculum est emptoris, in Iuris Professio - Festgabe M. Kaser, Wien-Köln-Graz, 1986, pp. 211 ss. e M. Pennitz, Die Gefahrtragung beim Weinverkauf im klassischen römischen Recht, in TR (Tijdschrift voor Rechtsgeschiedenis) 62 (1994), p. 251 ss.

27 Periculum est emptoris". in ZSS (Zeitschrift der Savigny-Stiftung für Rechtsgeschichte) 99 (1982), pp. 216 ss.

28 Traditio und Gefahrübergang, in ZSS (Zeitschrift der Savigny-Stiftung für Rechtsgeschichte) 106 (1989), p. 292 ss.

29 "Periculum" cit., p. 237.

30 Afric., 8 quaest., D. 19, 2, 33 e Paul. 3 epit. Alf., D. 18, 6, 13 e 15 pr.-1. 
Recordem-se, nesse sentido, os estudos de A. Rodger ${ }^{31}$ e G. MacCormack ${ }^{32}$ os quais, todavia, apenas retomam os resultados alcançados por E. Rabel, ${ }^{33}$ outro dentre os poucos romanistas que, no passado, apresentaram tese contrária à communis opinio.

Dignos de grande realce, no entanto, em prol da corrente minoritária, são os fundamentais estudos realizados sobre o nosso tema, ao final da última década, por M. Talamanca. ${ }^{34}$

Eles serviram de base, como se verá a seguir, para o estabelecimento dos pressupostos da hipótese de trabalho de nossa investigação.

\subsection{Hipótese de trabalho}

A nossa hipótese de trabalho -"Arbeitshypothese"-, fundada, como se disse, em proposta de M. Talamanca, parte da idéia de que no direito romano clássico, ao contrário de uma vigência ilimitada do princípio periculum est emptoris, teriam vigorado linhas de soluções diferenciadas em consonância com os diversos contextos problemáticos, que levavam em consideração, por exemplo, as distintas características do objeto da compra-e-venda e do poder de controle exercido sobre ele.

Desse modo, o direito romano clássico, em nosso tema, seria caracterizado como um "elastische Gebilde" ou seja, um modelo elástico, em que, dependendo das características e do tipo da fattispecie, os riscos eram atribuídos ora ao comprador (periculum est emptoris), ora ao vendedor (periculum est venditoris).

Assim, dentre essas características diversas da mercadoria vendida ou das heterogêneas circunstâncias contratuais de cada fattispecie, cuidando-se, por exemplo, da compra-e-venda de um bem consumível como o vinho, ou de uma coisa inconsumível como um imóvel, ou ainda, de uma relação contratual com incidência ou falta da bona fides, ou mesmo, de emptio venditio seguida ou não da eventual entrega da mercadoria, a solução poderia variar, imputando-se o periculum, em certos casos, ao comprador, em outros, ao vendedor.

Dentro dessa linha de pesquisa, em um período inicial de estudos, submeteuse à prova, primeiramente, a nossa mencionada Arbeitshypothese, buscando-se demonstrar em textos como, de um lado, Ulp. 34 ad ed. D. 23, 3, 14 e Pomp. 14 ad ed. D. 23, 3, 15), ${ }^{35}$

31 Emptio pertecta Revisited: a Study of Digest 18. 6. 8. 1, in TR (Tijdschrift voor Rechtsgeschiedenis) 50 (1982), p. 349 ss.

32 Alfenus Varus and the Law of Risk in Sale, in LQR (The Law Quarterly Review) 101 (1985), pp. 573 ss.

33 Gefahrtragung beim Kauf, in ZSS (Zeitschrift der Savigny-Stiftung für Rechtsgeschichte) 42 ( 1921), p. 543 ss.

34 Cf. Vendita cit., pp. 451 ss.; Considerazioni cit., pp. 217 ss.; e "Lex" ed "interpretatio" in Lab. 4, post. a. Iav. epit. D. 19,1,50, in Nozione formazione e interpretazione del diritto dall'età romana alle esperienze moderne - Ricerche dedicate al Professor Filippo Gallo, Napoli, 1997, p. 353 ss.

35 Cf. E. C. Silveira Marchi, "Periculum rei venditae" e "periculum dotis aestimatae", in Labeo Rassegna di diritto romano 47 (2001), pp. 384-410 [=Revista de Processo 93 (1999), p. 125-150. 
e, de outro, Paul. 3 epit. Alf. D. 18, 6, 13 e 15 pr. e Paul. 3 epit. Alf. D. 18, 6, 15, 1), ${ }^{36}$ que, dentre as diversas circunstâncias de fato de cada fattispecie a influenciar soluções diversas na jurisprudência romana clássica, o elemento da traditio ou entrega da mercadoria pode ter exercido um papel fundamental, com a aplicação do princípio res perit domino e atribuição dos riscos não ao comprador mas sim ao vendedor (periculum est venditoris, à semelhança do atual Direito Civil brasileiro).

Seguindo-se nessa hipótese de trabalho, analisamos depois os casos de emptio perfecta, por meio da exegese de textos como Pap. 3 resp. Frag. Vat. 16, Diocl. et Max. C. 4, 48, 5 (de 285 d.C.) [=Frag. Vat. 23] e especialmente do famoso fragmento Paul. 3 ad ed., D. 18, 6, 8 pr., de maneira a verificar se, também nessas fattispecie de venda condicional e de outros casos de emptio perfecta, a figura da traditio possa ou não ter influenciado, de modo relevante, a questão de atribuição de riscos na compra-e-venda. ${ }^{37}$

Revelou-se, todavia, nesse último estudo - acolhendo-se, mais uma vez, sugestão de M. Talamanca, ${ }^{38}$ contrária à communis opinio -, a possibilidade de ter-se apresentado no direito romano clássico, na verdade, uma disputa entre as duas conhecidas correntes ou escolas de juristas romanos, vale dizer, Proculeianos e Sabinianos, no tocante ao problema de atribuição de riscos contratuais na compra-e-venda.

É essa, pois, a partir de agora, a nova linha de raciocínio que se persegue em nossas investigações em tema de periculum rei venditae.

Tal suposição, levantada, como se disse, por M. Talamanca, ${ }^{39}$ poderia explicar o porquê da desde sempre conhecida contradição das fontes (especialmente nos fragmentos do Digesto) em nossa matéria, com a atribuição dos riscos ao comprador em inúmeros fragmentos, mas também, em um ou outro texto, ao vendedor.

Com base em tal hipótese de reconstrução histórico-dogmática do problema do periculum rei venditae, é possível que os juristas romanos pertencentes à Escola dos Sabinianos, como Juliano, Alfeno e Africano, tenham, desde o início, optado pelo princípio de atribuição dos riscos ao vendedor (periculum est venditoris), motivados, talvez, pela

36 Cf. MARCHI, E. C. Silveira. Acerca da "traditio" no âmbito do problema dos riscos na compra-e-venda Os casos das "camas vendidas" (Paul. 3 epit. Alf. D. 18,6,13 e 15 pr) e da "madeira comprada" (Paul. 3 epit. Alf. D. 18,6,15,1). Revista da Faculdade de Direito da Universidade de São Paulo, v. 99, p. 37-60, jan./dez. 2004.

37 Cf. MARCHI, E. C. Silveira. Compra-e-venda condicional e "emptio perfecta" em tema de riscos da coisa vendida ("periculum rei venditae"). Revista da Faculdade de Direito da Universidade de São Paulo, v. 103, p. $71-90$, jan./dez. 2008.

38 Considerazioni cit., p. 241-246 e 292-296.

39 Funda-se o autor - como declarado por ele próprio -, em suas grandes linhas, quanto a esse ponto específico, em hipótese interpretativa sugerida por E. Seckel-E. Levy, Die Gefahrtragung cit., p. 170 ss. Ressaltese, todavia que, não obstante reconhecer a influência desses dois grandes estudiosos alemães no ponto específico tratado, M. Talamanca deles discorda no tocante às suas conclusões gerais. 
configuração originária da compra-e-venda como um escambo imediato entre coisa e preço (e não como um negócio obrigacional, modelo que viria a se firmar mais tarde).

Já a Escola dos Proculeianos, representada em especial, nessa questão, por jurisconsultos como Labeão, Nerácio e Celso, teria aparentemente acolhido, em contrapartida, o princípio oposto, de atribuição dos riscos ao comprador (periculum est emptoris), atenuando-o, de um lado, pela admissão da responsabilidade por custodia por parte do vendedor e, de outro, pela doutrina da emptio perfecta.

A hipótese de um Schulenstreit, vale dizer, de uma luta ou disputa entre as duas Escolas, uma vez comprovada, representaria importante novidade nos estudos de Direito Romano, já que no rol de divergências entre as duas famosas correntes (sectae) de jurisconsultos romanos (especificação de nova species, validade do testamento em caso de condição impossível, ocupação de coisa achada etc. ), não costuma figurar essa posição diversa em tema de periculum rei venditae. ${ }^{40}$

De qualquer modo, essa proposta agora a ser seguida, como alertado pelo próprio M. Talamanca, dependerá de futuras demonstrações nas fontes.

3. Exegese de Gai. 10 ed. prov. D. 18, 1, 35, 5 a 7

Nesse caminho, além do exame a ser feito de fontes secundárias como Alex. C. 4, 48, 2 (de 223 d.C.), Ulp. 28 ad Sab. D. 18, 6, 1 pr.-1, Ulp. 28 ad Sab. D. 18, 6, 4, 1, e Paul. 5 ad Sab. D. 18, 6, 5, procede-se aqui ao aprofundamento da exegese, em especial, dos três seguintes textos:

Gai. 10 ed. prov. D. 18, 1, 35, 5:

In his quae pondere numero mensurave constant, veluti frumento vino óleo argento, modo ea servantur quae in ceteris, ut simul atque de pretio convenerit, videatur perfecta venditio, modo ut, etiamsi de pretio convenerit, non tamen aliter videatur perfecta venditio, quam si admensa adpensa adnumeratave sint. Nam si omne vinum vel oleum vel frumentum vel argentum quantumcumque esset uno pretio venierit, idem iuris est quod in ceteris rebus. Quod si vinum ita venierit, ut in singulas amphoras, item oleum, ut in singulos metretas, item frumentum, $u$ in singulos modios, item argentum, ut in singulas libras certum pretium diceretur, quaeritur, quando videatur emptio perfici. Quod similiter scilicet quaeritur et de his quae numero constant, si pro numero corporum pretium fuerit statutum.

\footnotetext{
40 Cf., para este ponto, os estudos de D. Liebs, Rechtsschulen und Rechtsunterricht im Prinzipat, in ANRW (Aufstieg und Niedergang der römischen Welt) 2.15 (1976), p. 244 ss., e G. L. Falchi, Le controversie fra sabiniani e proculeiani, Milano, 1981, p. 263 ss.
} 
Sabinus et Cassius tunc perifici ${ }^{4 \prime}$ emptionem existimant, cum adnumerata admensa adpensave sint, quia venditio quase sub hac condicione videtur fieri, ut <in singulas amphoras contrahatur aut $>^{42}$ in singulos metretas aut in singulos modios quos quasve admensus eris, aut in singulas libras quas adpenderis, aut in singula corpora quae adnumeraveris.

(=" $=$ Para aquelas coisas que devem ser pesadas, contadas ou medidas, como os cereais, o vinho, o óleo e a prata, ora se observa o mesmo que ocorre em relação às demais coisas, de maneira que, tão logo acordado o preço, a venda parece tornar-se perfeita, ora, todavia, não se considera perfeita a venda, mesmo acertado o preço, enquanto as coisas não foram medidas, pesadas ou numeradas. Assim, se todo o vinho, ou óleo, ou cereais, ou prata, em qualquer quantidade, fosse vendido por um preço único, valerá a mesma regra aplicável às demais coisas. Todavia, se o vinho tiver sido vendido por um preço certo por cada ânfora, ou, igualmente, o óleo por cada metreta, ou, igualmente, os cereais por cada módio, ou, igualmente, a prata por cada libra, indaga-se sobre quando parece aperfeiçoar-se a compra-e-venda. $\mathrm{O}$ mesmo semelhantemente e por certo se pergunta acerca daquelas coisas que, devendo ser contadas, tivessem seu preço estatuído por número de unidades. Sabino e Cássio opinam que a compra-e-venda será considerada perfeita quando se tenha contado, medido ou pesado, uma vez que a venda parece ter-se feito sob a condição < de que o acerto se deu (ou de que se contratou) por cada ânfora $>$, por cada metreta ou por cada módio que tivesse sido medido, ou por cada libra que tivesse sido pesada, ou por cada unidade que tivesse sido contada".).

Gai. 10 ed. prov. D. 18, 1, 35, 6:

Ergo et si grex venierit, si quidem universaliter uno pretio, perfecta videtur, postquam de pretio convenerit: si vero in singula corpora certo pretio, eadem erunt, quae proxime tractavimus.

(="Portanto, também se um rebanho tiver sido vendido, na verdade, todo ele por um preço único, a venda parece perfeita. Se, todavia, a venda foi contratada a um preço

${ }_{41}$ Quanto ao emprego, nesse texto, da terminologia relativa à emptio perfecta, ressalta v. Arangio-Ruiz, La compravendita II cit., p. 271, que o verbo perficere é usado nesse fragmento como exato sinônimo de contrahere, distinguindo-se o caso da compra que se "aperfeiçoa" quando do acordo sobre o objeto e o preço, e o caso da compra que se "aperfeicoará" somente em seguida ao cumprimento de certas providências.

42 Tal integração, proposta por T. Mommsen, é amplamente acolhida pela doutrina. Cf., por exemplo, V. ArangioRuiz, La compavendita II cit., p. 271, n.1, que julga tal integração "diplomaticamente più che plausibile e tale da recostruire perfettamente un senso che altrimenti si perderebbe" 
certo por cada corpo, ocorrerá o mesmo que há pouco já tratamos").

Gai. 10 ed. prov. D. 18, 1, 35, 7:

Sed et si doleario pars vini venierit, veluti metretae centum, verissimus est (quod et constare videtur) antequam admetiatur, omne periculum ad venditorem pertinere: nec interest, unum pretium omnium centum metratarum in semel dictum sit an in singulos eos.

(="Mas também no caso de venda de parte do vinho de um tonel, como, por exemplo, cem metretas, é muitíssimo verdadeiro que, antes da medição, todo o risco corre por conta do vendedor, não interessando ter-se fixado um só preço para todas as cem metretas, de uma só vez ou para cada uma delas".)

Nesses três fragmentos em exame, Gaio parece hipotisar quatro casos ou espécies de compra-e-venda, ou seja (por ordem de aparição e equivalência ${ }^{43}$ ):

Caso 1: Compra-e-venda de toda a mercadoria a um preco fixo total, vale dizer,"eu vendo toda a minha provisão de vinho, azeite, cereais ou prata a um preço único total" (D. 18,1,35,5: "nam si omne vinum...in ceteris rebus") ou "eu vendo todo meu rebanho a um preco único total" "(D. 18,1,35,6: Ergo et si grex...convenerit");

Caso 2: Compra-e-venda de parte da mercadoria a um preço fixo por cada unidade de medida, vale dizer, "eu vendo <parte da minha provisão de $>$ vinho, azeite, cereais ou prata, a um preço certo por cada ânfora, metreta, módio ou libra" (D. 18,1,35,5: "quod si vinum...fuerit statutum") ou "eu vendo cem metretas de parte do meu tonel de vinho a um preço certo por cada metreta" (D. 18,1,35,7: “. . an in singulos eos");

Caso 3: Compra-e-venda de toda a mercadoria a um preço fixo por cada unidade de medida, vale dizer, "eu vendo $<$ toda a minha provisão de > vinho, azeite, cereais ou prata, a um preço certo por cada ânfora, metreta, módio ou libra" (D. $18,1,35,5$ : "quod si vinum...fuerit statutum"), o "eu vendo todo o meu rebanho a um preço certo por unidade" (D. 18,1,35,6: "...si vero in singula corpora certo pretio, eadem erunt, quae proxime tractavimus"); e, por fim,

Caso 4: Compra-e-venda de parte da mercadoria a um preço único total, vale dizer "eu vendo cem metretas de parte do meu tonel de vinho a um preço único total" (D. 18,1,35,7:

43 Cf. W. Ernst, "Periculum" cit., p. 234-236. O autor, porém, apesar de descrever os cinco casos, prefere enumerálos em apenas três. 


\section{"Sed et si ex doleario......nec interest, unum pretium omnium centum metretarum in semel dicutum sit...".}

Note-se que esse último caso não é mencionado dentre os exemplos constantes do conceito de venda sujeita a contagem, pesagem e medição apresentado por L. Cunha Gonçalves, como visto de início. Todavia, tal caso 4 não parece, a rigor, pelo menos quanto ao cálculo do preço final da mercadoria a ser pago, diferenciar-se muito do caso 2: em outros termos, se "eu vendo cem metretas de vinho por um preço único total de dois mil sestércios", isso equivale a dizer que "eu estou vendendo tais cem metretas a vinte sestércios por cada uma delas"

De qualquer maneira, é certo que em ambos os casos haverá sempre a necessidade do ato de medição das cem metretas de vinho, de modo a separá-las do todo do tonel.

Na exegese conjunta dos três fragmentos, o cerne da questão reside na frase antequam admetiatur, omne periculum ad venditorem pertinere (isto é, "antes da medição, todo o risco corre por conta do vendedor"), presente no último texto, D. 18,1,35,7, de importância fundamental na fundamentação de teses antagônicas em tema de periculum rei venditae.

A communis opinio tradicional, ${ }^{44}$ ainda hoje prevalente (mesmo que não tão hegemônica como no passado), entende que, ao se atribuir o periculum ao vendedor antequam admetiatur, procura-se indicar que, antes da medição, a compra-e-venda ainda não estaria "perfeita" apesar de já "celebrada": os riscos, então, continuariam a cargo do vendedor, só passando para o comprador (periculum est emptoris) após a verificação daquele ato de admetiri, ou seja, com o "aperfeiçoamento" desse contrato (emptio perfecta).

Em outros termos: normalmente, os momentos de "celebração" e de "perfeição" da venda coincidiam, valendo o contrato a partir da troca de consensos entre o comprador e o vendedor, ou seja, mediante o simples acordo de vontade entre eles acerca do objeto e do preço.

Assim, celebrada e aperfeiçoada compra-e-venda, os riscos passariam imediatamente a correr por conta do comprador.

Em casos excepcionais, porém, aqueles dois momentos poderiam não coincidir, de maneira que a venda, apesar de celebrada, ainda não estaria aperfeiçoada, arcando enquanto isso o vendedor com o periculum. ${ }^{45}$

\footnotetext{
${ }_{44}$ Cf., por exemplo, F. Wieacker, Die juristische Sekunde - Zur Legitimation der Konstruktionsjurisprudenz, in Festschrift für E. Wolf 60. Geburtstag, 1962, p. 432, M. Kaser, Das römische Privatrecht I cit., pp. 552-553, R. Knütel, Kauf und Pacht cit., p. 44, F. Peters, Rücktrittsvorbehalte cit., 1973, p. 147, A. Guarino, Diritto Privato Romano cit., pp. 912-913, e M. Marrone, Istituzioni cit., p. 485, nota 150.

45 Cf. M. Marrone, Istituzioni cit., p. 485, nota. 150.
} 
Tais casos excepcionais, em que a venda celebrada ainda não era perfecta, corresponderiam, como ensinava M. Kaser ${ }^{46}$, à compra e venda condicional (D. 18,6,8 pr.) ou mesmo a termo, às hipóteses em que a merx devesse ser produzida pelo vendedor, apresentasse vícios ou defeitos, ou estivesse em posse alheia (D.19,2,33), e, por fim, às situações em que a mercadoria ainda não fosse claramente "individualizada" como na compra e venda alternativa, compra-e-venda com cláusula de degustação, e, por fim, a compra-e-venda com o preço dependente da pesagem, contagem e medição da mercadoria, justamente aquela contemplada nos três fragmentos em exame, D. 18, 1, 35, 5-7.

Nesses textos - e mais especificamente na fattispecie do primeiro -, como acentuado por V. Arangio-Ruiz, ${ }^{47}$ um dos principais representantes dessa communis opinio, poder-se-ia de modo claro distinguir, em correspondência a C. 4,48,2, duas diversas situações: 1) acertada a compra, a um preço global, de todo um estoque de certo mantimento, independentemente de sua exata quantidade, o contrato é considerado aperfeiçoado ou existente; nesta situação, continuava o autor, pressupõe-se que, segundo Gaio, ainda que ele não o diga expressamente, mas dada a referência ao problema do periculum rei venditae no precedente $\S 4$ e no sucessivo $\S 7$, o risco passaria imediatamente ao comprador); 2) ajustada, no entanto, a compra por cada unidade de medida, o contrato, segundo Sabino e Cássio, aperfeiçoar-se-ia somente quando da medição, interpretando-se este último evento como uma condição suspensiva.

Em face da referência à opinião dos mestres da Escola Sabiniana, poder-seia ainda hipotisar, segundo V. Arangio-Ruiz, que Gaio, originariamente, fizesse menção ao provável entendimento oposto dos proculianos: esses teriam decidido tratar-se não de condição, mas de uma obrigação das partes, de modo que, deixando o comprador de cumpri-la, passaria o risco a correr por sua conta.

Por sua vez, W. Ernst, ${ }^{48}$ ainda que adepto da doutrina dominante, favorável à classicidade do princípio periculum est emptoris, apresenta fundamentação diversa, baseando-se parcialmente em resultados alcançados por W. Flume. ${ }^{49}$

$\mathrm{O}$ autor, diante daqueles casos excepcionais de emptio perfecta, entende inexistente o contrato antes do momento do seu "aperfeiçoamento", 50 ainda que o mesmo já tivesse sido "celebrado": em outros termos, antes da verificação daquelas situações de exceção, necessárias para a sua "perfeição" - dentre os quais, justamente a emptio venditio dependente de pesagem, contagem e medição referida nos textos em exame, D. 18, 1, 35,

\footnotetext{
46 Das römische Privatrecht I cit., p. 552-553.

47 La compravendita II cit., p. 271-273.

48 "Periculum" cit., p. 234 e ss.

49 Der bedingte Rechtsakt nach den Vorstellungen der römischen Klassiker, in ZSS 92 (1975), p. 96 e ss.

so No mesmo sentido, já antes dele, cf. F. Schulz, Classical Roman Law, 1951, p. 533: "emptio perfecta cannot possibly mean anything else but the conclusion of the contract"
} 
5 a 7 -, a compra-e-venda seria considerada como não existente e, assim, não produtiva de qualquer efeito.

A "perfeição" da compra e venda, portanto, seria uma exigência não para a aplicação do princípio periculum est emptoris, mas para o surgimento do próprio contrato, como negócio jurídico válido.

Como corolário, dever-se-ia concluir, segundo W. Ernst, que os romanos não tivessem admitido qualquer limitação ou exceção ao princípio periculum est emptoris.

Nos casos, pois, de compra e venda imperfecta, a atribuição dos riscos ao vendedor decorreria simplesmente da aplicação da regra geral casum sentit dominus (ou res perit domino). Não existindo contrato (=compra e venda imperfecta), o vendedor, em caso de perecimento da coisa, não poderia nada exigir do comprador. O emprego, nestes casos, da expressão periculum venditoris não indicaria, portanto, a adoção de uma especial regra em matéria de riscos na compra e venda, mas a mera conseqüência ou efeito de se considerar inexistente a emptio venditio "imperfecta"

$\mathrm{Na}$ exegese específica desses três fragmentos, eles confirmariam, segundo W. Ernst," que a compra-e- venda "mit Zumessungserfordernis" vale dizer "com exigência de medição" (lato sensu), não era considerada pelos clássicos como existente ou efetivada enquanto não verificada a pesagem, contagem ou medição.

Assim, nas hipóteses de compra-e-venda ad mensuram, quer de toda merx quer de parte dela, enquanto não realizada a medição (lato sensu) ou efetuada a separação, os riscos, segundo Gaio, correriam por conta do vendedor, por não haver ainda um contrato.

A mesma concepção valeria, segundo W. Ernst baseando-se, neste ponto, também nos resultados alcançados por F. Casavola ${ }^{52}$ e J.A.C. Thomas ${ }^{53}$-, para as hipóteses de aperfeiçoamento da compra-e- venda sob o ponto de vista do certum pretium (casos 2 e 3 supra): faltando a determinação do preço total, como nos $\$ \S 5$ ("quod si vinum"rell.) e 6 ("...si vero"rell.), e estando, pois, imperfeita a venda, essa era pelos clássicos considerada como não concluída. Nao se trataria, pois, adverte W. Ernst, de ratificação ou complementação de um contrato já existente, como querem alguns.

Assim, portanto, conclui o autor, perecendo a coisa antes da determinação do preço total (casos 2 e 3 supra), o prejuízo seria do vendedor, não precisando o comprador pagar o preço, eis que não existia ainda uma compra e venda válida ou existente.

Como se vê, tanto esse entendimento de W. Ernst quanto aquele de V. Arangio-Ruiz situam-se dentro da tese tradicional do periculum est emptoris: os três textos seriam a prova de que, ocorrida a medição, ou seja, "passando a existir" o

\footnotetext{
s1 "Periculum" cit., p. 234-236.

52 "Emptio pondere numero mensura", in Scritti per il centenario della Casa editrice Jovene, Napoli, 1954 (=Sententia legum tra mondo antico e moderno I, Napoli, 2000), p. 551 ss.

53 Marginalia on certum pretium, in TR 35 (1967), p. 88 e ss.
} 
contrato (W. Ernst) ou tendo ele se "aperfeiçoado" (V. Arangio-Ruiz), os riscos passariam imediatamente ao comprador.

Embora respeitáveis tais exegeses, resta o aspecto de que, nas fontes analisadas, jamais se afirma, de modo claro e expresso, que celebrado o contrato, o risco passa ao comprador. É certo que isso poderia ser deduzido do do fato de que a medição poderia equipar-se ao "surgimento" ou "aperfeiçoamento" do contrato. No entanto, tal ponto permanece sempre duvidoso.

De qualquer modo, essas duas interpretações conformes à communis opinio não são de modo algum decisivas: realizada a medição, e, portanto, "surgido" ou "aperfeiçoado" o contrato, pode-se, todavia, também supor que ter-se-ia realizado a tradição. Em outros termos, a traditio, nesses casos, poderia coincidir com a medição.

Os textos, portanto, só podem, a rigor e sem discussão, constituir prova de que, antes da medição-entrega, os riscos correm por conta do vendedor.

E tal conclusão, obviamente, pode servir a qualquer das duas correntes doutrinárias em tema de periculum rei venditae: periculum est emptoris ou periculum est venditoris.

Resta um outro aspecto: Gaio, ao declarar em D. 18, 1, 35, 7 que, enquanto não realizada a medição, todos os riscos correriam por conta do vendedor, quereria se referir, ainda segundo W. Ernst, ${ }^{54}$ apenas ao caso de perecimento total, ou seja, periculum em sentido técnico.

Poder-se-ia, pois, indagar, segundo W. Ernst, qual seria, nesses casos de compra e venda "mit Zumessungserfordernis", a solução clássica em hipótese de mera deterioração.

Com base nos indícios presentes na segunda frase de Frag.Vat. 16, ${ }^{55}$ ao se tratar da compra-e-venda de genus de parte de um estoque ou provisão, no qual se afirma não suportar o comprador qualquer risco ("nullum periculum"), poder-se-ia supor, segundo W. Ernst, que o prejuízo pela deterioração caberia ao vendedor.

Assim, apesar das incertezas, poder-se-ia deduzir que, nos casos de comprae-venda ad mensuram, o risco pela deterioração da coisa antes da medição (lato sentu) era do vendedor segundo o direito clássico.

Aceitável, por último, segundo o autor, seria a proposta de E. Seckel - E. Levy, de que essa questão tivesse sido objeto de controvérsia dentre os juristas: Gaio

\footnotetext{
54 "Periculum" cit., p. 236.
}

5s Pap. 3 resp., Frag. Vat. 16:"Vino mutato periculum emptorem spectat, quamvis ante diem pretii solvendi vel condicionem emptionis impletam id evenerit. Quod si mille amphoras certo pretio corpore non demonstrato vini vendidit, nullum emptoris interea periculum erit." (="O risco pela deterioração do vinho compete ao comprador, ainda que isto tenha ocorrido antes do dia do pagamento do preço ou do verificar-se da condição da venda. Porém, se mil ânforas de vinho, por um preço certo, e sem que fossem elas especificadas, tivessem sido vendidas, o risco, neste interim, não caberá ao comprador"). 
teria dela tratadb em seguida ao quaeritur. Objeto dessa controvérsia poderia ter sido a dúvida se também a compra-e-venda sujeita ad mensuram pudesse ter efeitos retroativos, da mesma maneira como, em geral, se apresentava idêntica questão quanto à compra e venda condicional em geral.

Não haveria, por fim, contradição, concluía W. Ernst, entre uma tal solução hipotizadai em matéria de compra-e-venda ad mensuram e aquela adotada por Sabino e Cássio em D. 18, 6, 8 pr. in fine, em tema de compra-e-venda condicional, em que se atribui o risco ao comprador: na primeira a fixação de um preço não era mais possível, pois o comprador não mais mediria um vinho já deteriorado ou transformado em vinagre.

Cabe aqui, em se tratando da exegese de D. 18, 1, 35, 5-7, recordar-se também a reconstrução histórico-dogmática, não obstante viciada pelo antigo método da "Interpolationenjagd", proposta pelo líder da corrente minoritária contrária à adoção do princípio periculum est emptoris já pelo direito romano clássico, vale dizer, F. Haymann, buscando-se, todavia, considerar apenas os seus argumentos de ordem substancial - e não obviamente de forma.

Tratando do conceito de emptio perfecta, com particular atenção à compra e venda de vinho, F. Haymann, ${ }^{56}$ por meio justamente da exegese, em especial, de D. 18 , $1,35,5-7$, sustentava que tal noção teria sido introduzida pelos compiladores, através da interpolação de tais textos.

Coerentemente à sua tese em tema de periculum rei venditae, segundo a qual, para o direito romano clássico, os riscos caberiam ao vendedor (periculum est venditoris) e não ao comprador, o autor apontava como interpolada a frase sed omne periculum ad emptorem pertinere: na concepcao dos clássicos, o comprador, antes da entrega, só responderia pelos riscos decorrentes da deterioração natural do vinho, arcando o vendedor com todos os demais tipos de periculum: "Darum rührt das sed omnen periculum ad emptorem pertinere schwerlich von Ulpian her, die Kompilatoren wollen alle Gefahr der Veränderung oder Zerstörung durch die Hintertür des harmlos scheinenden sed-Satzes auf den Käufer überwalzen, obwohl für den Klassiker überhaupt nur die besondere Gefahr des inneren Verderbs in Frage kam" 57

Em sua exegese de D. 18, 1, 35, 5-7, F. Haymann, inicia observando que as noções teóricas expressas neste texto, se aplicadas na praxe, além de gerarem enormes dificuldades práticas, pouco tratadas pelos compiladores, conduziriam a um resultado inaceitável: qualquer "Spezieskauf" somente poderia tornar-se "perfecta", se houvesse a colaboração ou atuação conjunta de ambas as partes contraentes no ato de "admetiri" de

56 Textkritische II cit., p. 99 e ss.

s7 Textkritische II cit., p. 110. 
modo que, em termos teóricos, seria impossível a verificação de qualquer mora, quer do vendedor, quer do comprador.

Contra tais noções opor-se-ia uma passagem de Catão - De agricultura 148 -, que trata das cláusulas contratuais na compra de barril de vinho.Percebe-se claramente nesse fragmento que o "admetiri" podia ocorrer do lado de uma só das partes, sendo, portanto, a perfeição da compra completamente independente daquele ato. No mesmo sentido manifestar-se-ia Ulpiano em D. 18,6,1,2-4, texto, segundo ele, substanciamente genuíno.

A compra-e-venda no direito clássico, portanto, sustentava F. Haymann com base naqueles três textos, aperfeiçoava-se independentemente de qualquer medição. $\mathrm{O}$ ato de medir, assim como o de pesar e o de contar, indicariam, na verdade, segundo o autor, fundando-se em Varrão (Rer.rust. II 2,5-6), o exato momento da transmissão da propriedade através da traditio, e, daí, a passagem do periculum ou riscos ao comprador. ${ }^{58}$

Por outro lado, como se deduziria dos trechos não espúrios de D. 45, 1, 120 , D. 18, 1, 7, 1 e D. 18, 1, 35, pr.-1, e de Frag. Vat. 9, não seria requisito para o surgimento do contrato, segundo o direito clássico, a fixação do pretium na maneira como exigida pelos compiladores na concepção justinianéia da emptio perfecta.

Também quanto ao pressuposto da individualização do objeto da compra, no modo como concebido pelos defensores da emptio perfecta, o pensamento dos clássicos, no entender de F. Haymann, seria diverso. Para esses, como atestado por D. 45, 1, 115, a perfeição do contrato não dependia dessa exata individualização, mas apenas da objetiva determinação da prestação devida, de acordo com os critérios fixados pelas partes.

A doutrina da emptio perfecta, interpolada pelos compiladores, corresponderia perfeitamente - concluía F. Haymann - à estrutura da compra e venda do direito privado grego. Não tendo esse último ordenamento conhecido uma compra-e-venda consensual do tipo da romana, mas somente uma "Barkauf". ou seja, uma compra-e-venda à vista, com prestações "Zug-um-Zug" ou simultâneas, tornava-se sempre necessário que houvesse a exata e efetiva fixação do objeto e do preço, antes da qual o contrato não poderia "aperfeiçoar-se" ou vir a existir.

Na verdade, segundo o autor, ${ }^{59}$ o pensamento clássico em tema de periculum rei venditae - com respeito, em especial, à compra e venda de vinho - estaria estampado, principalmente, em Frag. Vat. 16, interpretado à luz de Catão, em De agricultura, 148.

Com base nesse depoimento de Catão e na interpretação a contrariis da declaração de Papiniano de que corpore non demonstrato vini vendidit, nullum emptoris

\footnotetext{
58 Textkritische II cit. (nota 2 supra), p. 103: „Wohl aber vollzieht sich im Normalfall seit alters in der Tat der Übergang des periculum auf den Käufer mit dem admetiri. Denn in dem Zumessem, Zuwägen, Zuzählen vollzieht sich die Tradition und der Eigentumsübergang, wie für den Kauf von Schafen Varro betont".

s9 Textkritische II cit., especialmente p. 98-99 e 108-109.
} 
interea periculum erit, sustentava F. Haymann em conclusão: o comprador, como regra geral no direito clássico, arcava com o periculum apenas em seguida à entrega da coisa vendida, ou à ocorrência de "Annahmeverzug des Käufers" ou seja, mora daquele na aceitação da merx.

No entanto, em casos de compra-e-venda de vinho, derivado de um estoque determinado - "Kauf aus einem bestimmten Vorrat (corpus)" -, o comprador, excepcionalmente, antes da traditio, respondia apenas pela deterioração natural do vinho (acor et mucor), correndo por conta do vendedor todos as outras causas de deterioração do vinho ou riscos pela perda da coisa.

Esta excepcional responsabilização do comprador, no entanto, também era excluída nos casos de compra e venda com cláusula de degustatio, enquanto essa não se realizasse. Os compiladores teriam, então, generalizado a atribuição dos riscos ao comprador para qualquer compra sine mensura.

Em outros termos, o comprador, no entendimento dos justinianeus, passava a responder, já antes da entrega, por qualquer risco, mesmo na compra e venda que não fosse de estoque determinado, ou seja, compra e venda em que não é necessária qualquer medição - sine mensura. Já nos casos de compra e venda de coisas fungíveis, isto é, cum mensura, enquanto os clássicos atribuiam os riscos ao vendedor até a "Messung" ou medição, identificada por eles com a traditio, os compiladores, apesar de distribuir os riscos da mesma forma, teriam introduzindo o conceito de emptio perfecta, equiparando aquela medição à conclusão ou surgimento do contrato ("aperfeiçoamento" no sentido justinianeu).

Assim sendo - concluía F. Hayman -, os textos concernentes à compra e venda de coisas fungíveis teriam sido interpolados pelos compiladores, de forma a se coadunarem com o novo princípio geral periculum est emptoris, de validade geral em época justinianéia. ${ }^{60}$

Resta, por fim, na exegese desses três fragmentos de Gaio, referirmo-nos às conclusões de $\mathrm{M}$. Talamanca ${ }^{61}$ alcançadas em interpretação conjunta com o famoso texto de Pompônio acerca de venda condicional e emptio perfecta, vale dizer, D. 18, 6, 8 pr.

A sua tese parte do pressuposto, como acima já se disse, de ter havido, no direito romano clássico, uma importante divergência entre as Escolas dos Sabinianos e aquela dos Proculeianos em tema de periculum rei venditae.

\footnotetext{
60 Coerentemente com essa nova doutrina, segundo F. Haymann, teriam, então, os compiladores interpolado, de acordo os mesmos critérios, vários outros textos, dentre os quais, em especial, além de D. 18,1,35,7, também D. $18,6,1$, pr.-1, D. $18,6,5$, e, por fim, C. 4, 48, 2.

61 Considerazioni cit., p. 262 e ss. mas, principalmente, p. 265-266.
} 
Segundo M. Talamanca, ${ }^{62}$ pelo menos até o final do séc. IId.C.ce primeiros decênios do séc II d.C. os sabinianos seriam contrários ou resistentes aro princípio "periculum est emptoris" Foi só a partir dessa época que eles passam a se render, conduta essa simbolizada pela decisão de Juliano, 15 dig., em D. 18, 5, 5, 2, no qual atribui-se o risco ao comprador no caso da mors servi. Em contrapartida, já nos primeiros tempos da época imperial, poder-se-ia perceber a prevalência do princípio contrário "periculum est emptoris" entre os proculeianos, como atestado por Labeão em Ulp. 32 ad ed., D. 19, 1, $13,22$.

Os motivos que explicam a prevalência, a partir do séc. II d.C., da opinião dos proculeianos ("p.e.e."), no entender do autor, residiriam, originariamente, no regime do commodum/incommodum acerca dos acréscimos ou decréscimos naturais. ${ }^{63}$ No caso do incommodum (perda de parte do terreno ou de parte das ovelhas) não haveria dúvidas entre os juristas acerca da responsabilidade do comprador, ainda que não tivesse havido a traditio. A princípio, em contrapartida, se a coisa, ao invés de perder apenas parte, efetivamente perisse, o risco seria do vendedor, já que ainda proprietário.

Nessa situação, o periculum em sentido técnico, vale dizer, o perecimento total da coisa vendida, ${ }^{64}$ seria do vendedor e não do comprador. Dada a contradição lógica entre as consequências jurídicas decorrentes desses casos de incommodum e as daqueles casos de periculum a jurisprudência, em geral, a partir do séc. II d. C., teria então começado a equiparar as duas situações, consolidando-se, assim, o princípio "periculum est emptoris"

Os proculeianos, por sua vez, a julgar por Pomp. D. 18, 6, 8 pr., teriam, de início, sido ainda mais radicais, continua M. Talamanca, ${ }^{65}$ ao acolher o princípio periculum est emptoris até mesmo nas vendas condicionais ainda pendente condicione, reconhecendo a validade dessa regra até mesmo com efeitos retroativos, vale dizer, desde a celebração do contrato.

Os responsáveis pela limitação do princípio "p.e.e." à doutrina da emptio perfecta não teriam sido, contudo, os proculianos, mas juristas do séc. II, como Paulo e Papiniano, ou mesmo alguns dos últimos sabinianos, como Juliano, em uma época na qual o princípio sabiniano "p.e.v." já estaria quase abandonado.

E como o teriam feito? A doutrina da emptio perfecta, pelo que deflue das fontes, teria sido originalmente construída, segundo propõe $M$. Talamanca, pelos próprios sabinianos, como consta justamente dos fragmentos em exame, D. 18, 1, 35, 5 a 7. Todavia, tal doutrina não teria, em origem, relação com o problema do periculum rei venditae, mas

\footnotetext{
$62 \quad$ Considerazioni cit., p. 245 e 294.

63 Cf. Vendita cit., p. 418 e ss.

64 Considerazioni cit., p. 294.

65 Considerazioni cit., p. 265-266.
} 
sim com o problema da admissão ou não dos efeitos retroativos da condição suspensiva, em casos como os da aquisição dos frutos da res vendita e do decurso do prazo para usucapião.

Nessas situações, continua M. Talamanca, os proculeianos admitiriam a retroatividade, enquanto os sabinianos teriam procurado limitar tais efeitos retroativos (salvo algumas exceções ${ }^{66}$ ) justamente por meio da construção da doutrina da emptio perfecta aplicada à condicio.

Em outros termos: para os sabinianos, no caso, por ex., dos frutos, eles pertenceriam ainda ao vendedor (e não ao comprador) enquanto a venda não se "aperfeiçoasse", ou seja, enquanto a condição não se verificasse ou ocorresse; só depois desse momento é que os frutos caberiam ao comprador. Nessa situação, pois, a condição suspensiva não teria efeitos retroativos.

Por fim, conclui M. Talamanca, com base em Gai. D. 18, 1, 35, 5 a 7, a mesma aplicação original da emptio perfecta teriam os sabinianos adotado em relação às vendas sujeitas a pesagem, contagem e medição, entendendo-as como análogas às vendas condicionais.

Assim, também no tocante a elas, o recurso à doutrina da perfectio pelos sabinianos nada teria a ver, de início, com o problema do periculum rei venditae, mas sim com a questão, combatida entre as duas Escolas, acerca da retroatividade dos efeitos da condição, admitida pelos proculeianos mas não por aqueles outros.

A julgar por Paul. 3 ad ed., D. 8, 6, 8 pr., só depois, em época tardo-clássica, que juristas como Papiniano, Juliano e principalmente Paulo, ao adotarem o princípio proculeiano periculum est emptoris, teriam procurado limitar tal dogma, valendo-se do esquema da emptio perfecta. ${ }^{67}$

\section{Conclusão}

De nossa parte, na exegese de D. 18, 1, 35, 5-7, devemos observar que, na compra-e-venda ad mensuram, a pesagem, contagem e medição desses tipos de mercadorias provavelmente corresponderiam ou equivalessem, no mais das vezes, na praxe, à traditio ou entrega dos produtos: com isso, torna-se bastante difícil, a partir do relato de Gaio nesses três fragmentos, extrair argumentos decisivos em favor da communis opinio ou contra ela.

Diante de tal empecilho, melhor nos parece seguir, pois, a proposta reconstrutiva de $M$. Talamanca ${ }^{68}$ em matéria de periculum rei venditae - contrária à

\footnotetext{
Considerazioni cit., p. 266, nota 174.

Considerazioni cit., p. 266-270 e especialmente 266.

Considerazioni cit., p. 241-246 e 292-296.
} 
communis opinio -, de ter-se apresentado no direito romano clássico, na verdade, uma disputa entre as duas conhecidas correntes ou escolas de juristas romanos, vale dizer, proculeianos e sabinianos, acerca do problema de atribuição de riscos contratuais na compra-e-venda.

É essa, pois, a partir de agora, a nova linha de raciocínio que se procurará perseguir em nossas investigações futuras em tema de periculum rei venditae.

São Paulo, setembro de 2010.

\section{Referências}

ABATINO, Barbara. L' "emptio venditio" di "res quae pondere numero mensura constant" Principi, giuristi, prassi. 2005-2006. Tese (Doutorado) - Università degli Studi di Napoli "Federico II", Napoli.

ARANGIO-RUIZ, Vincenzo. La compravendita in diritto romano I. 2. ed. Napoli: 1956. . La compravendita in diritto romano II. reimpr. Napoli: 1956.

ARNÒ, Carlo. La teorica del periculum rei venditae nel diritto romano classico. Giurisprudenza Italiana, 49 p. 2091897.

. Note minime sul § 3 Inst. 3,23. Archivio Giuridico, n. 62, p. 540, 1899.

La costituzione ultima del Códice de periculo et commodo rei venditae. Studi Brugi, p. 154, 1910.

Sul c. 23 dei Fragmenta Vaticana. In: Memorie della R. Academia di Scienze Lettere ed Arti in Modena 91910.

BENITEZ LOPES, Maria M. La venta de vino y otras mercancias em la jurisprudência romana. Madrid: 1994.

BETTI, Emilio. "Periculum" - Problemi del rischio contrattuale in diritto romano clássico e giustinianeo. JUS 5 (1954), p. 333 ss. [=Studi in onore di P. de Francisci I, Milano, 1956, p. 131 ss.];

BIONDI, Biondo. Istituzioni di diritto romano. 4. ed. Milano: 1972.

BUCKLAND, W.W. A text-book of roman law. 2. ed. Cambridge, 1950.

BURDESE, A. Vendita. Direito Romano. NNDI: Nuovissimo Digesto Italiano, 201975.

CANNATA, Carlo Augusto. La compravendita consensuale romana: significato di uma struttura, in Vendita e trasferimento della proprietà nella prospettiva storico-comparatistica 2. Milano: 1991.

CASAVOLA, F. Emptio pondere numero mensura. In: Scritti per il centenario della Casa editrice Jovene, Napoli, 1954 (=Sententia legum tra mondo antico e moderno I, Napoli, 2000). 
GONÇALVES, Luiz da Cunha. Da compra-e-venda no direito comercial brasileiro. 2. ed. São Paulo, 1950.

DEREMBURG, H. Pandekten 2. 5. ed. Berlin: 1897.

DINIZ, Maria Helena. Curso de direito civil brasileiro. Teoria das obrigações contratuais e extracontratuais. 26. ed. São Paulo: 2010.v. 3.

ERNST, Wolfgang. Periculum est emptoris. Zeitschrift der Savigny-Stiftung für Rechtsgeschichte, 99, p. 216, 1982.

FALCHI, G. L. Le controversie fra sabiniani e proculeiani. Milano, 1981.

FERCIA, Riccardo. Emptio perfecta e vendita di genere: sul problema del tradere in C 4.48.2. In: GAROFALO, Luigi (Org.). La compravendita e l'interdipendenza delle obbligazioni nel diritto romano. Padova: 2007.

FLUME, W. Der bedingte Rechtsakt nach den Vorstellungen der römischen Klassiker. ZSS 921975.

p. 96 e ss.;

GIRARD, P. F. Manuel élémentaire de droit romain. 8. ed. Paris: 1929.

GUARINO, A. Diritto privato romano. 12. ed. Napoli: 2001.

HAUSMANINGER, H.; SELB, W. Römisches privatrecht. 4. ed. Köln: 1997.

HAYMANN, Franz. Textkritische Studien zum römischen Obligationenrecht. I- Über Haftung für custodia. II- "Periculum est emptoris" Zeitschrift der Savigny-Stiftung für Rechtsgeschichte, 40, 1919. p. 167 ss. e p. 44 ss.;

Zur klassizität des "periculum emptoris". Zeitschrift der Savigny-Stiftung für Rechtsgeschichte, 48, 1928. p. 314 ss.

HONSELL, H. Römisches Recht. 4. ed. Berlin-Heildelberg: 1997.

KARLOWA, O. Römische rechtsgeschichte 2. Leipzig: 1901.

KASER, Max. Römisches Privatrecht I. Das altrömische, das vorklassische und klassische Recht. 2. ed. München: 1972.

KONSTANTINOVITCH, M. Le "periculum rei venditae" em droit romain. Lyon: 1923.

KNÜTEL, Rolf. Augusto Teixeira de Freitas e il "periculum" nella compravendita. In: AUGUSTO Teixeira de Freitas e il diritto latinoamericano. Padova: 1988. p. 489 ss.

Kauf und Pacht bei Abzahlungsgeschäften im römischen Recht. In: STUDIEN im römischen Recht M. Kaiser zum 65. Geburtstag gewindmet. Berlin: 1973. p. 35 ss.

; Kunkel, Wolfgang; Honsell, Heinrich. Römisches Recht. Berlin-Heidelberg: 1987.

LIEBS, D. Rechtsschulen und Rechtsunterricht im Prinzipat. ANRW (Aufstieg und Niedergang der römischen Welt) 2.15 (1976), p. 244. 
MCCORMAK, Geoffrey. Alfenus Varus and the Law of Risk in Sale. LQR (The Law Quarterly Review) 101 (1985), pp. 573 ss.;

MARRONE, Matteo. Istituzioni di diritto romano. 2. ed. Palermo: 1996.

SILVA, Oscar Joseph de Plácido e. Vocabulário Jurídico. 25. ed. Rio de Janeiro: 2004.

PENNITZ, M. Das periculum rei venditae. Ein Beitrag zum "aktionenrechtlichen Denken" im römischen Privatrecht. Wien: 2000.

PETERS, Franz. Periculum est emptoris. In: FESTGABE für M. Kaser. Wien-Köln-Graz: 1986. p. 221 ss.;

RABEL, Ernest. Gefahrtragung beim Kauf. Zeitschrift der Savigny-Stiftung für Rechtsgeschichte, 42, 1921.

RODGER, A. Emptio pertecta Revisited: a Study of Digest 18. 6. 8. 1. Tijdschrift voor Rechtsgeschiedenis. 50, p. 349, 1982.

VENOSA, Silvio Salvo. Direito civil: contratos em espécie. 10. ed. São Paulo: 2010 . Código civil interpretado. 2. ed. São Paulo: 2011.

SARGENTI, Manlio. Rischio contrattuale (diritto romano). In: Enciclopedia del Diritto 40 (1989). SCHULZ, F. Classical Roman Law. London: 1951.

SECKEL, E.; Levy, E. Die Gefahrtragung beim Kauf im klassichen römischen Recht. Zeitschrift der Savigny-Stiftung für Rechtsgeschichte, 47, p. 117-263, 1927.

MARCHI, Eduardo Cesar Silveira. Acerca da "traditio" no âmbito do problema dos riscos na compra-e-venda - Os casos das "camas vendidas" (Paul. 3 epit. Alf. D. 18,6,13 e 15 pr) e da "madeira comprada" (Paul. 3 epit. Alf. D. 18,6,15,1). Revista da Faculdade de Direito da Universidade de São Paulo, São Paulo, v. 99, p. 37-60, jan./dez. 2004.

MARCHI, Eduardo Cesar Silveira. Compra-e-venda condicional e "emptio perfecta" em tema de riscos da coisa vendida ("periculum rei venditae"). Revista da Faculdade de Direito da Universidade de São Paulo, São Paulo, v. 103, p.71-90, jan./dez. 2008.

MARCHI, Eduardo Cesar Silveira. "Periculum rei venditae" e "periculum dotis aestimatae". Labeo Rassegna di Diritto Romano, 47, p. 384-410, 2001.

TALAMANCA, Mario. Vendita (diritto romano). In: Enciclopedia del Diritto 46 (1993).

. Considerazioni sul "periculum rei venditae". In: Seminários Complutenses de Derecho Romano 7 (1995).

"Lex" ed "interpretatio" in Lab. 4, post. a. Iav. epit. D. 19,1,50. In: NOZIONE formazione e interpretazione del diritto dall'età romana alle esperienze moderne. Ricerche dedicate al Professor Filippo Gallo. Napoli: Jovene, 1997. p. 353 ss. 
THIELMANN, Georg. Traditio und Gefahrübergang. Zeitschrift der Savigny-Stiftung für Rechtsgeschichte, n. 106, p. 292, 1989.

THOMAS, J. A. C. Marginalia on certum pretium. TR, 35, p. 88, 1967.

WIEACKER, Franz. Die juristische Sekunde. - Zur Legitimation der Konstruktionsjurisprudenz. In: Festschrift für E. Wolf 60. Geburtstag: 1962.

ZIMMERMANN, R. The Law of Obligations. Roman Foundation of the Civilian Tradition. Cape Town: 1990. 